\title{
32. PALEONTOLOGICAL SUMMARY OF DEEP SEA DRILLING RESULTS FROM LEG 35, SOUTHEAST PACIFIC BASIN
}

\author{
Fred Weaver, Antarctic Marine Geology Research Facility, Dept. of Geology, \\ Florida State University, Tallahassee, Florida \\ Fred Rögl, Geology Department, Museum of Natural History, Vienna, Austria \\ Bilal U. Haq, Woods Hole Oceanographic Institution, Woods Hole, Massachusetts \\ and \\ Hans-Joachim Schrader, Geologisch-Palaontologisches Institut und Museum der Universität Kiel, \\ Kiel, Olshausenstrasse 40/60, F. R. Germany
}

\section{INTRODUCTION}

The major objectives of the paleontolgical program during Leg 35 were to (1) establish and refine high latitude Antarctic biostratigraphy, (2) increase our understanding of the paleobiogeography of all microfossil groups, and (3) investigate changes in the paleooceans and paleoclimates of the Antarctic during the late Mesozoic and Cenozoic.

Due to scientific priorities, mechanical difficulties, and poor weather conditions, no continuous coring was attempted during Leg 35 , consequently, only age determinations and several observations on paleoenvironments are contributed by the shipboard paleontological staff. All age determinations and calculations of sedimentation rates are based upon correlations to established Antarctic biostratigraphic zonal schemes, standard low latitude zonations, and land sections in Australia, New Zealand, Japan, and Europe (McCollum, 1975; Chen, 1975; Hays and Opdyke, 1967; Abbott, 1972; Donahue, 1970; Ciesielski, 1975; Schrader, 1973; Bolli, 1966; Walters, 1965; Hornibrook, 1961; Daniels and Spiegler, 1974; Blow, 1969; Martini and Worsley, 1970; and Berggren, 1972, 1973).

\section{ACCUMULATION RATES}

Figure 1 illustrates the sediment accumulation rates at all Leg 35 sites, which are calculated from established paleontological datums and biostratigraphic zones. Because of the lack of continuous coring and the frequent paucity and poor preservation of microfossils, these calculations are at best only averages. A detailed discussion of these results is included in the site summaries (Chapters 3-6, this volume).

It is apparent from Figure 1 that two major trends in sediment accumulation occur throughout the southeast Pacific Basin during the Neogene. Most Miocene, middle to late Pliocene, and Pleistocene sediments are characterized by relatively slow accumulation rates of approximately 2 to $3 \mathrm{~cm} / 1000 \mathrm{yr}$. In contrast, the latest Miocene to middle Pliocene sediment sequences recovered during Leg 35 exhibit vastly increased rates of accumulation on the order of 10 to $20 \mathrm{~cm} / 1000 \mathrm{yr}$. This significant increase must surely be related to an intensification of Antarctic glaciation and subsequent increased deposition of sediments by bottom currents.
Unfortunately, it is not possible to elaborate on this major regional event from the few sediment cores recovered during this leg.

\section{SITE 322}

(EASTERN BELLINGSHAUSEN ABYSSAL PLAIN)

\section{Age Determinations}

Siliceous microfossils were used exclusively in dating all sediments in Cores 1 through 10 . The sediment interval between Sections 322-1-1 and 322-2-2 is Pliocene in age based upon identification of the Helotholus vema radiolarian zone of Chen (1975), and the Nitzschia interfrigidaria and Nitzschia praeinterfrigidaria diatom zones of McCollum (1975) within these cores (Figure 2). These zones represent the entire Gauss and middle to late Gilbert magnetic epochs ( $T=2.43$ to 4.6 m.y. B.P.).

Samples examined between $322-2, \mathrm{CC}$ and $322-4, \mathrm{CC}$ are assigned a late Miocene age, based upon the occurrence of two radiolarian species, Eucyrtidium sp. aff. E. inflatum and Stichocorys peregrina. This age assignment is corroborated by the diatom flora which are representative of the Denticula hustedtii Zone of McCollum (1975). Denticula hustedtii and Trinacria excavata occur commonly throughout this interval. Sample 322-4, CC contains rare specimens of Denticula lauta, which became extinct in the North Pacific at approximately 5.5 m.y. B.P. (Schrader, 1973). Cores 322-5 through 322-10 are assigned a Miocene age, based on the sporadic occurrence of Eucyrtidium cienkowskii group radiolarians, throughout these intervals. The basal 5.5 meters of sediment overlying basement within Core 11 contain a sparse arenaceous foraminiferal fauna which is restricted to the Oligocene-early Miocene in well-known land sections throughout the world (Rögl, this volume). Stratigraphically important species include Haplophragmoides carinatus, Cyclammina incisa, and Cyclammina cf. japonica (Figure 2).

\section{SITE 323 \\ (BELLINGSHAUSEN ABYSSAL PLAIN)}

\section{Age Determinations}

Few to common, moderately well preserved siliceous microfossils occur throughout the first nine sediment cores at Site 323. Cores 323-1 and 323-2 are Pliocene in 


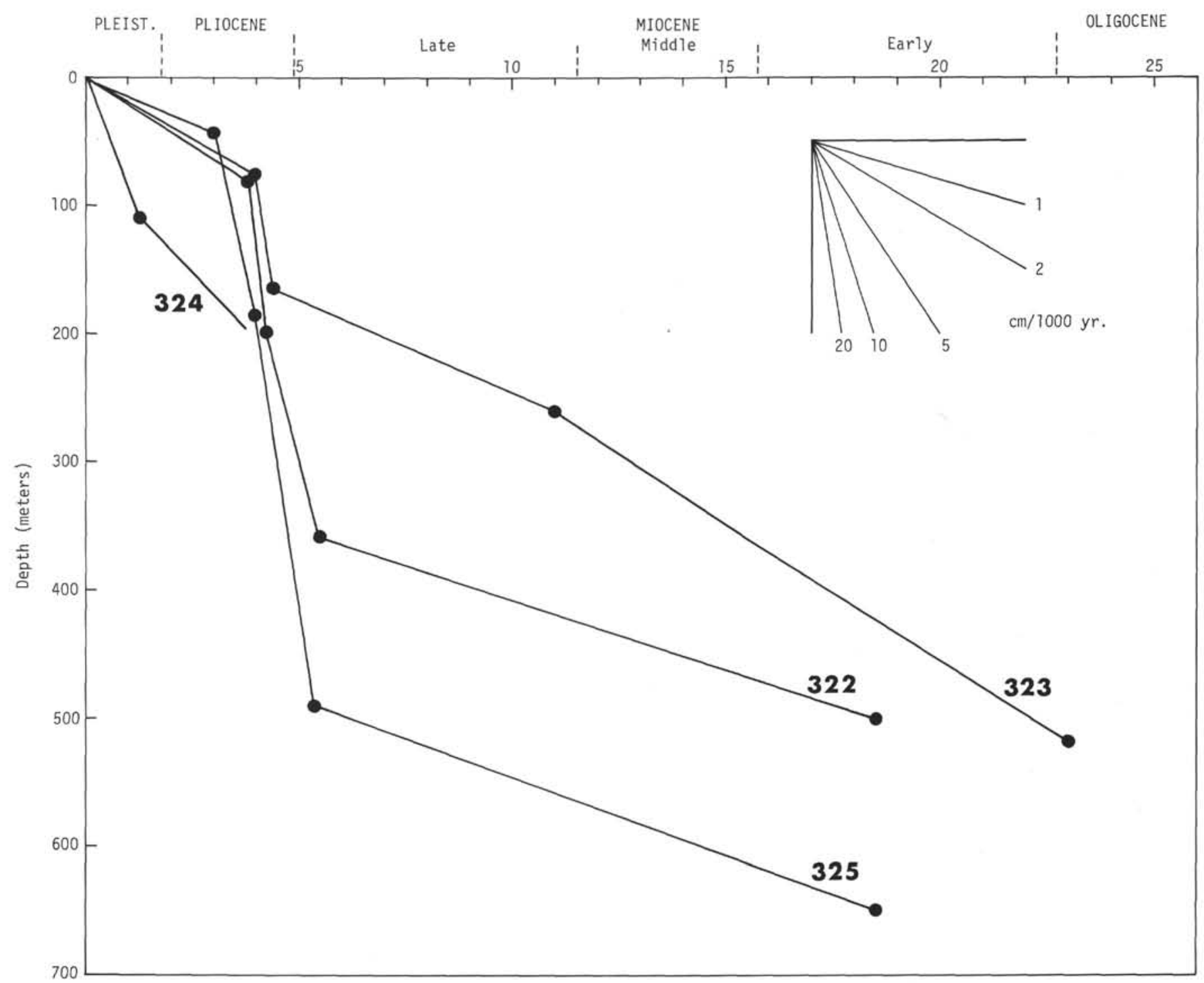

Figure 1. Sediment accumulation rates, DSDP Leg 35.

age, and several biostratigraphic zones are recognized within these sediments. They include the Nitzschia interfrigidaria, Nitzschia praeinterfrigidaria, and Denticula hustedtii diatom zones of McCollum (1975), the Helotholus vema and Tau radiolarian zones of Chen (1975) and Hays and Opdyke (1967), and the Dictyocha pseudofibula and Distephanus boliviensis silicoflagellate zones of Ciesielski (1975). The absolute time represented by these zones includes the Gauss and middle to late Gilbert magnetic epochs ( $\mathrm{T}=4.0$ to 2.43 m.y. B.P.)

Sections 323-3-1 and 323-3-2 are early late Miocene in age ( $\mathrm{T}=\sim 10$ to $11 \mathrm{~m} . \mathrm{y}$. B.P.) and fall within the Denticula hustedtii/Denticula lauta diatom zone of McCollum (1975). Silicoflagellate occurrences also indicate a late Miocene age for these cores (Figure $3 ; M$. circulus Zone).

Sample 323-3, CC through Core 323-7 are middle Miocene in age ( $\mathrm{T}=\sim 11$ to $15.5 \mathrm{~m} . \mathrm{y}$. B.P.) based upon correlation to the biostratigraphy established from Leg 28 sediments. Diagnostic zones identified within this interval include the Denticula antarctica-Coscinodiscus lewisianus diatom zone, the Antarctissa conradae and Spongomelissa dilli-Calocyclas disparidens radiolarian zones, and the Dictyocha mutabilis and Corbisema triacantha silicoflagellate zones (Figure 3). Cores 323-61, 6, CC, and 7, CC contain Rhaphidodiscus marylandicus, a stratigraphically important diatom species which is restricted in low latitudes to the early middle Miocene ( $T=\sim 14$ to 15 m.y. B.P.). The last common occurrence of this species has been correlated to the N9 and N10 planktonic foraminiferal zones of Blow (1969).

Cores 323-8 and 323-9 are correlated to the base of the Corbisema triacantha silicoflagellate zone. Since these cores are below the earliest occurence of $R$. marylandicus, and within the $C$. triacantha Zone, they may possibly represent the latest early Miocene.

Cores $323-10$ to $323-13$ contain arenaceous foraminifera similar to the Oligocene-early Miocene assemblage encountered within core 11 at Site 322 .

No age determinations were possible in the barren sediments between $323-14$ to $323-15-5$; however, from Section $323-15-5$ to basement, both calcareous nan- 


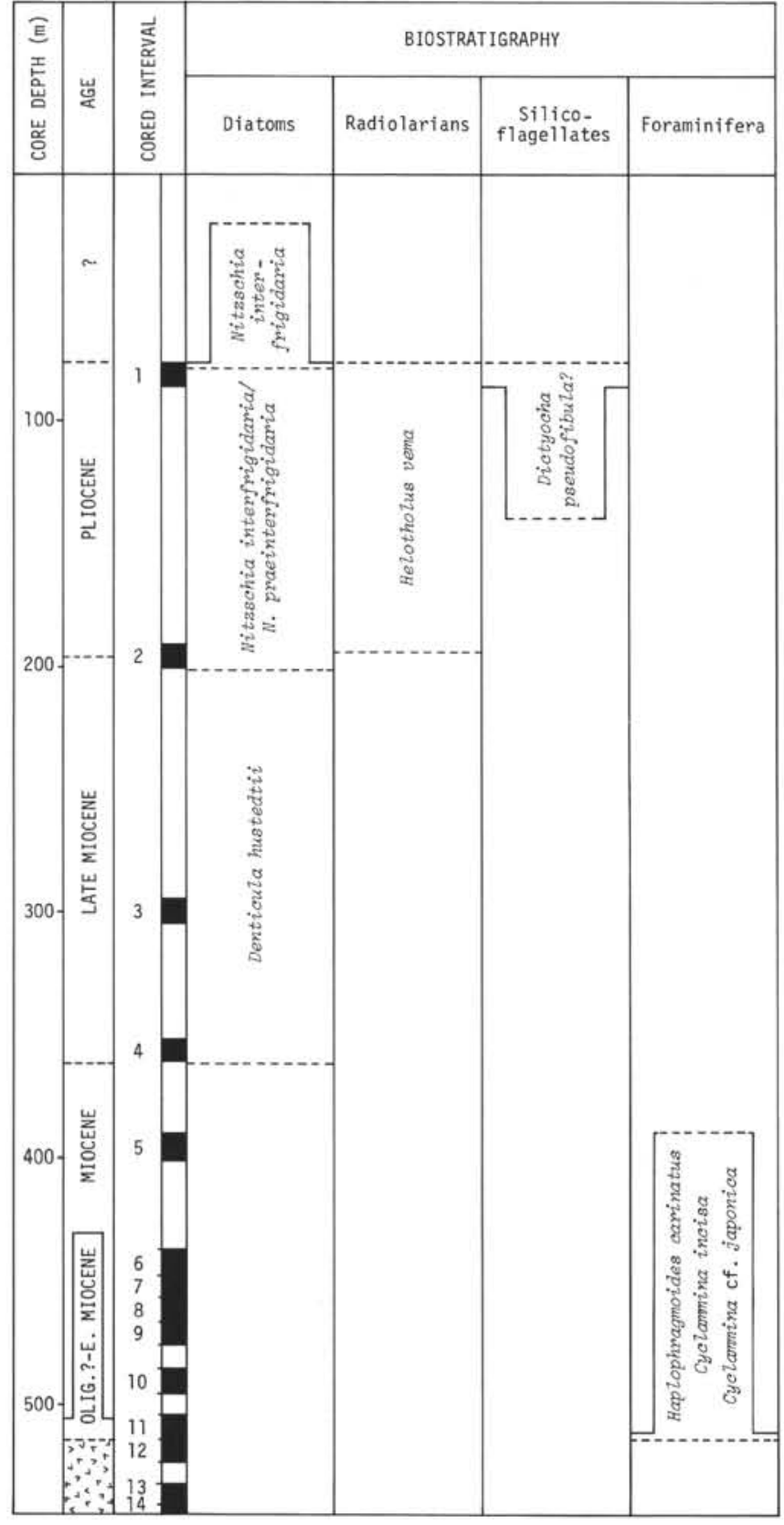

Figure 2. Biostratigraphic summary of Site 322.

noplankton and planktonic foraminifera allow a rather precise early Paleocene (Danian) age designation.

Sections 323-15-6 to 323-16-2 fall within the Chiasmolithus danicus nannoplankton zone (NP3), while 323-16-2 to 323-16-4 represents the Cruciplacolithus tenuis Zone (NP2). Samples examined between 323-16-4, $53-55 \mathrm{~cm}$ to $17-1,80-82 \mathrm{~cm}$ are barren, but $323-17$, CC and 323-18-4 contain nannoplankton characteristic of a late Maestrichtian age (Haq, this volume).

Moderately well preserved planktonic foraminifera occurring between Sections 323-15-5 and 323-16-2 also indicate an early Paleocene (Danian) age. This interval is within the Globigerina edita Zone, which includes the G. eugubina and G. pseudobulloides zones of Bolli (1966) (Figure 3).

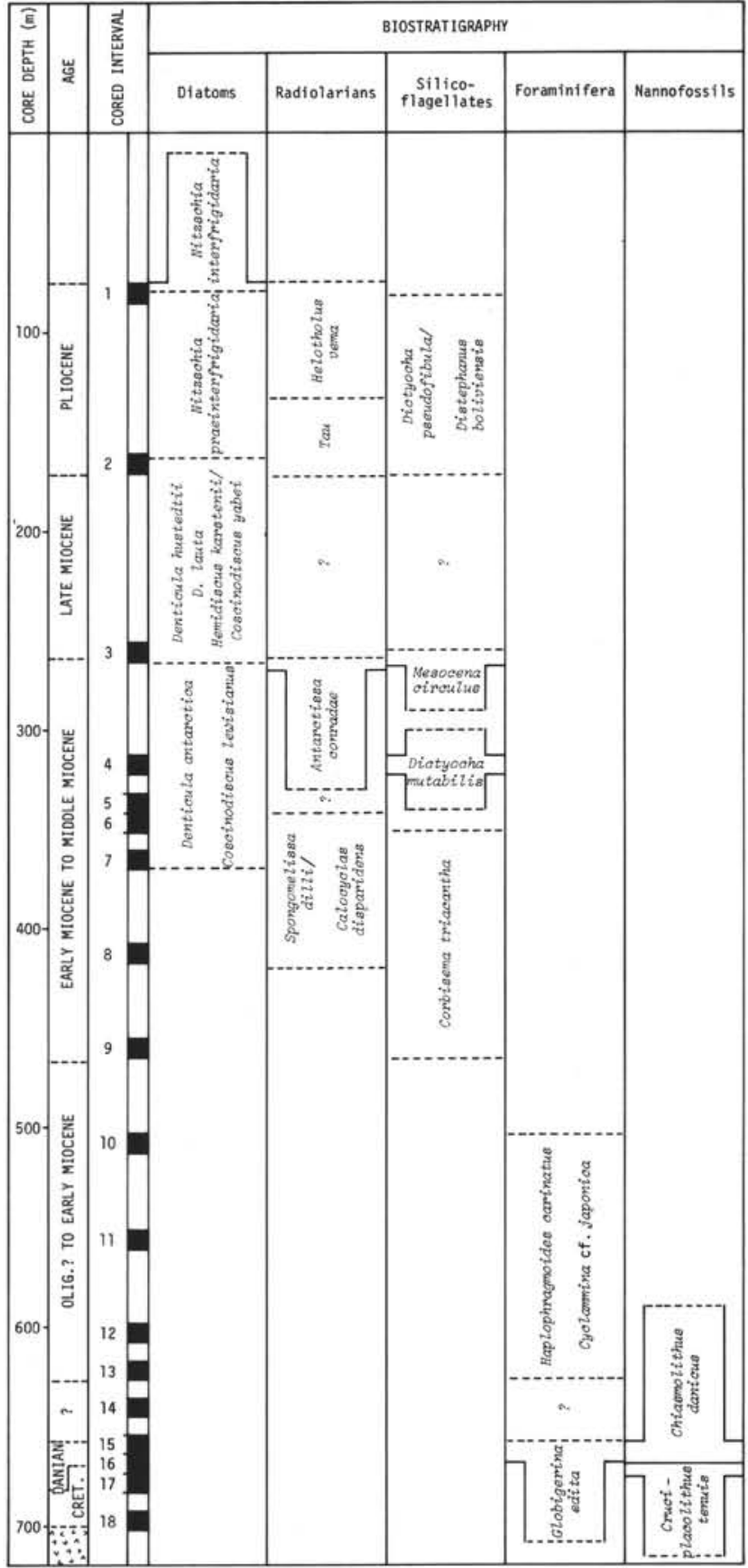

Figure 3. Biostratigraphic summary of Site 323.

\section{SITE 324 \\ (UPPER CONTINENTAL RISE)}

\section{Age Determinations}

Sediments recovered at Site 324 are essentially barren of calcareous microfossils, except for a sparse population of the typical high latitude form of the planktonic foraminifera $N$. pachyderma (left coiled) in Cores 5 through 8.

Core 324-1 contains common to abundant siliceous microfossils within several intervals. Diatoms and radiolarians present in Core 1 are diagnostic of a 
Pleistocene age (Figure 4). Biostratigraphic zones recognized include the Antarctissa denticulata and Saturnalis circularis radiolarian zones of Chen (1975) and the Nitzschia kerguelensis, Rouxia californica, and Actinocyclas ingens zones of Abbott (1972) and Donahue (1970). These zones represent the entire Brunhes and middle to late Matuyama magnetic epochs.

The diatom flora in Cores 324-2 through 324-4 also indicates a Pleistocene age for these cores $(A$. ingens Zone). The sediments below Core 4 through Core 9 are essentially barren of microfossils, but Sample 324-9, CC does contain a mixed assemblage of both radiolarians and diatoms. The tentative early Pliocene age assignment for 324-9, CC is based on the dominance of Pliocene indices at this level.

\section{SITE 325 \\ (UPPER CONTINENTAL RISE)}

\section{Age Determinations}

The upper 400 meters of sediment at Site 325 are essentially Pliocene in age. The biostratigraphy of Cores 325-1 through 325-5 is illustrated in Figure 5. Except for the Theocalyptra bicornis spongothorax radiolarian zone of Chen (1975), these cores contain the same siliceous microfossil zones identified from Pliocene sediments at Sites 322 and 323. The Theocalyptra bicornis spongothorax Zone is shown to span the Pliocene/Miocene boundary in the Southern Ocean (Weaver, this volume), although it was initially defined to be restricted to the late Miocene (Chen, 1975).

Cores 325-7 through $325-10$ are dated as early Miocene primarily on the basis of foraminifera (Figure 5 ), however Core 8, Section 2 contains species of Bolboforma (a probable algal cyst), whose stratigraphic limits are restricted to the Oligocene-early Miocene based upon comparison to similar species described from sediments in northern Germany (Daniels and Spiegler, 1974).

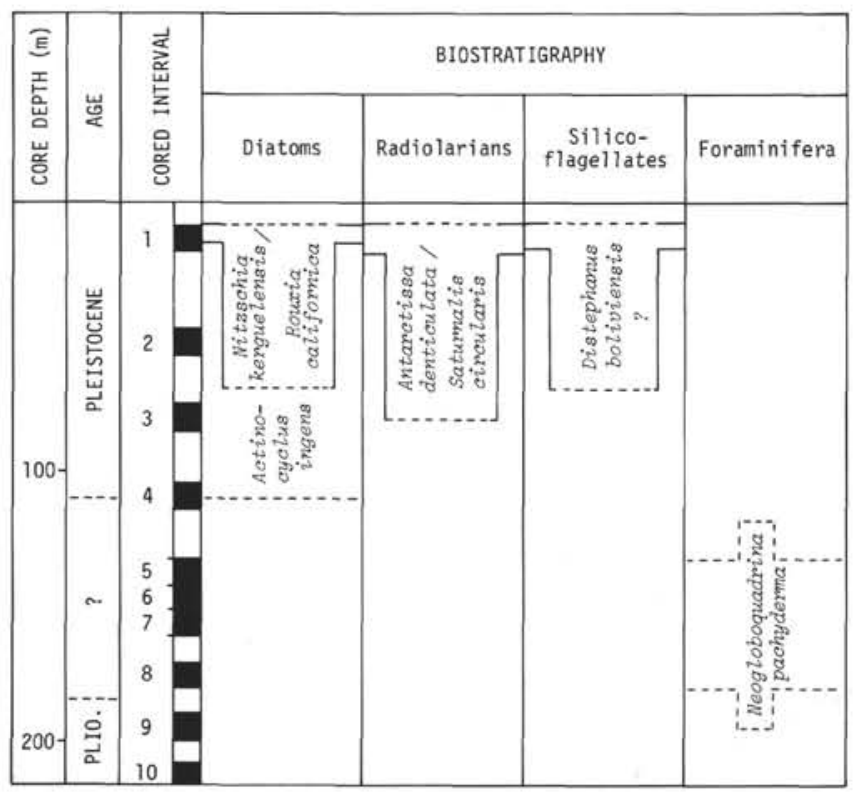

Figure 4. Biostratigraphic summary of Site 324.

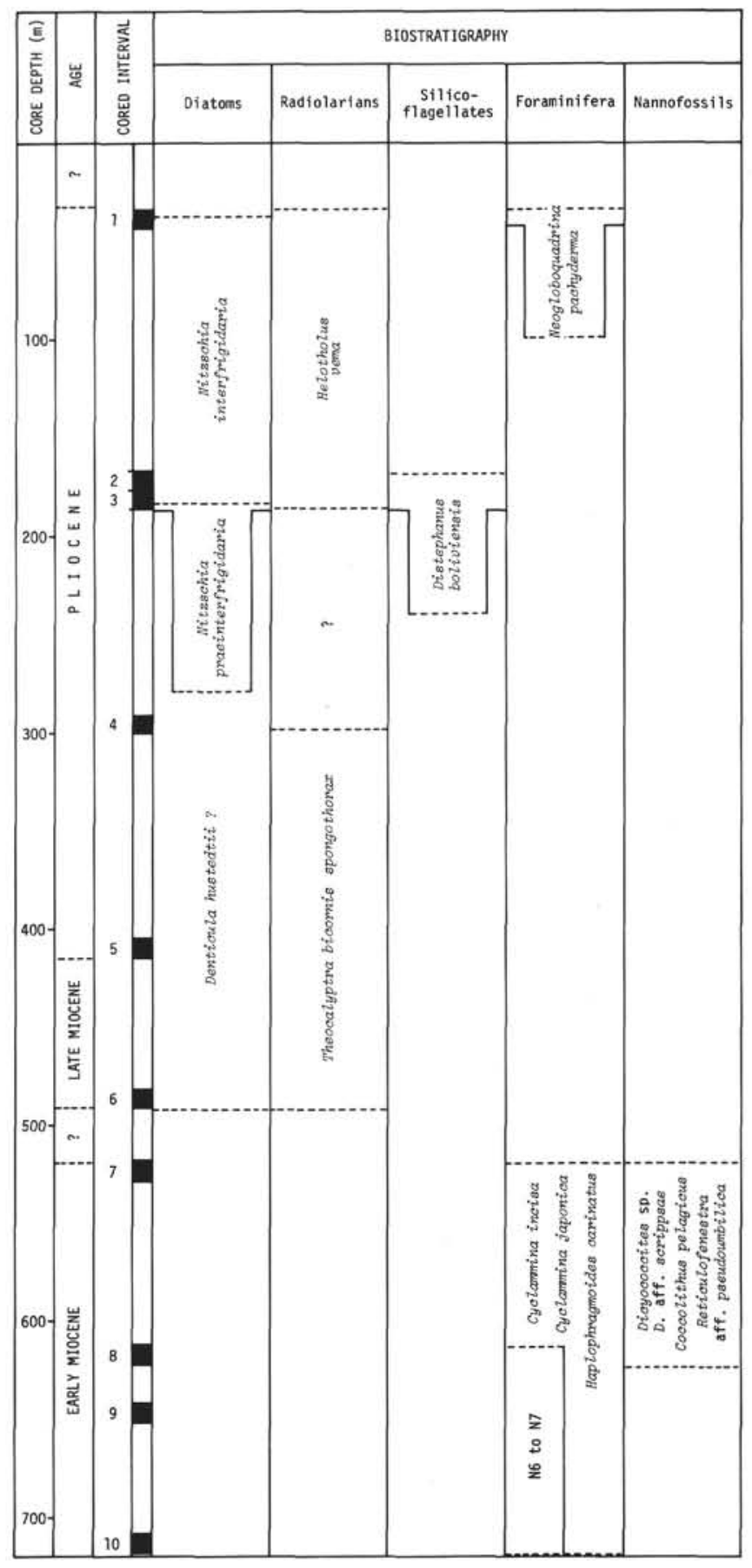

Figure 5. Biostratigraphic summary of Site 325.

An arenaceous foraminiferal fauna dated as Oligocene-early Miocene, and similar to the assemblage that occurs at Sites 322 and 323, was identified in Cores 7 through 10 (Figure 5). Core 10, Section 1 contains the planktonic foraminifer Globorotalia zealandica incognita which is known to range through the $G$. woodi connecta and early G. trilobus trilobus zones in New Zealand (late N6 to early N7) (Walters, 1965; Jenkins, 1973). This early Miocene age is supported by the occurrence of a few specimens of the Globorotalia peripheroronda group within Core 325-8. 


\section{PALEOENVIRONMENTAL INTERPRETATION}

Although only a limited amount of paleontological data are compiled from Leg 35 sediments, it is possible to make several observations concerning Tertiary paleocurrent activity, paleoclimates, and paleoenvironments of deposition for the southeast Pacific Basin and Antarctic continental rise.

\section{Paleocurrents}

Site 322, Cores 6 through 9 , contain foraminifera that are poorly preserved and highly polished indicating transportation by active bottom currents within the Bellingshausen Abyssal Plain. A precise age determination is not possible for this interval, however, it is most likely middle to late Miocene in age (Figure 2).

At Site 323, located in the Bellingshausen Abyssal Plain, evidence suggests a significant increase in bottom current activity during the Paleogene. An Fe-claystone unit 24 meters thick occurs between Sections 323-15-4 and 323-14-2. Paleontological data indicate that this unit should represent the entire Oligocene, Eocene, and late Paleocene. It seems highly unlikely that this unit is only a compressed sedimentary section. We strongly believe that a major hiatus can be inferred within this interval and that it is probably related to deep-sea erosion induced by paleocirculation changes related to the opening of the Drake Passage during the Paleogene.

\section{Paleoclimates}

Middle Miocene and early late Miocene sediments from Samples 323-3-2, 323-4, CC, and 323-6-1 contain few to common collosphaerid and orosphaerid radiolarians. These radiolarians are only found in modern tropical and subtropical water masses, therefore, their abundance in Miocene sediments may represent periodic incursions of warm waters into the southeast Pacific during the middle and early late Miocene.

From the nine sediment cores recovered on the continental rise at Site 324 , only Core 1 contains several intervals of siliceous ooze and clay. These intervals include a typical late Quaternary Antarctic fauna and flora. Since this location lies south of the seasonal limits of ephemeral sea-ice $\left(68^{\circ} \mathrm{S}\right)$, recent sediments on the continental rise at Site 324 consist of barren glacial marine sediments. The diatom-rich units in Core 1, therefore, probably represent a recession in the northern limits of sea-ice resulting from a climatic warming during the Pleistocene.

\section{Paleoenvironments}

From the close examination of microfossil assemblages recovered from sediments collected during Leg 35, it appears that depositional environments, both in the Bellingshausen Abyssal Plain and Antarctic continental rise, remained primarily below the calcium carbonate dissolution boundary during the Cenozoic. Calcareous microfossils were only encountered at few intervals in Paleocene (Danian), early Miocene, and Pleistocene sediments (Figures 3-6). It is interesting to note that in contrast to the worldwide rise in the CCD boundary during the Danian (Worsley, 1974), we record a deepening of the CCD in the Bellingshausen Abyssal Plain (Site 323). The reason for this phenomenon is presently unresolved.

During the Danian a well-preserved and highly diverse calcareous and arenaceous benthonic foraminiferal fauna existed within the Bellingshausen Abyssal Plain. Planktonic/benthonic foraminiferal ratios and the species assemblage are characteristic of upper to middle bathyal depths (1500-2000 m) during this time.

The depositional environment of the Antarctic continental rise and Bellingshausen Abyssal Plain during the early Miocene appears to have been generally the same. Although some calcareous material was deposited along the continental rise during the early Miocene, the fauna is dominated by a characteristic deep-water arenaceous foram assemblage indicative of middle to lower bathyal depths (2000-3000 m).

Beginning in the middle Miocene, siliceous microfossils, for the first time, become the dominant faunal and floral component in sediments recovered at all Antarctic sites drilled during Leg 35 . This transition in microfossil assemblages from the early to the middle Miocene indicates a major change in the physical oceanography of the southeast Pacific and probably relates to the buildup of the Antarctic polar ice cap beginning in the middle Miocene.

\section{REFERENCES}

Abbott, W.H., 1972. Vertical and lateral patterns of diatomaceous ooze found between Australia and Antarctica: PhD Thesis, Department of Geology, University of South Carolina.

Berggren, W.A., 1972. A Cenozoic time scale-some implications for regional geology and paleobiogeography: Lethaia, v. 5, p. 195-215.

1973. The Pliocene time scale: calibration of planktonic foraminiferal and calcareous nannoplankton zones: Nature, v. 243, p. 391-397.

Blow, W.H., 1969. Late middle Eocene to recent planktonic biostratigraphy. In Bronnimann, P. and Renz, H.H. (Eds.): Internatl. Conf. Plankt. Microfossils, 1st Proc. Geneva.

Bolli, H.M., 1966. Zonation of Cretaceous to Pliocene marine sediments based on planktonic foraminifera: Bol. Inform. Asoc. Venez. Geol. Min. Petrol., v. 9, p. 3-32.

Chen, P., 1975. Antarctic Radiolaria, Leg 28, Deep Sea Drilling Project. In Frakes, L.A., Hayes, D.E., et al., Initial Reports of the Deep Sea Drilling Project, Volume 28: Washington (U.S. Government Printing Office), p. 437513.

Ciesielski, P.F., 1975. Neogene and Oligocene silicoflagellates from cores recovered during Antarctic Leg 28, Deep Sea Drilling Project: Biostratigraphy and Paleoecology. In Frakes, L.A. and Hayes, D.E., et al., Initial Reports of the Deep Sea Drilling Project, Volume 28: Washington (U.S. Government Printing Office), p. 625-691.

Daniels, C.H.V. and Spiegler, D., 1974. Bolboforma n. gen. (Protozoa?)-eine neue stratigraphisch wichtige Gattung aus dem Oligozän/Miozän Nordwestdeutschlands: Paläont. Z., v. 48 , p. $57-76$.

Donahue, J.G., 1970. Diatoms as Quaternary biostratigraphic and paleoclimatic indicators in high latitudes of the Pacific Ocean: PhD Thesis, Faculty of Pure Science. Columbia University.

Hays, J.D. and Opdyke, N.D., 1967. Antarctic Radiolaria, magnetic reversals, and climatic change: Science, v. 158, p. 1001 . 


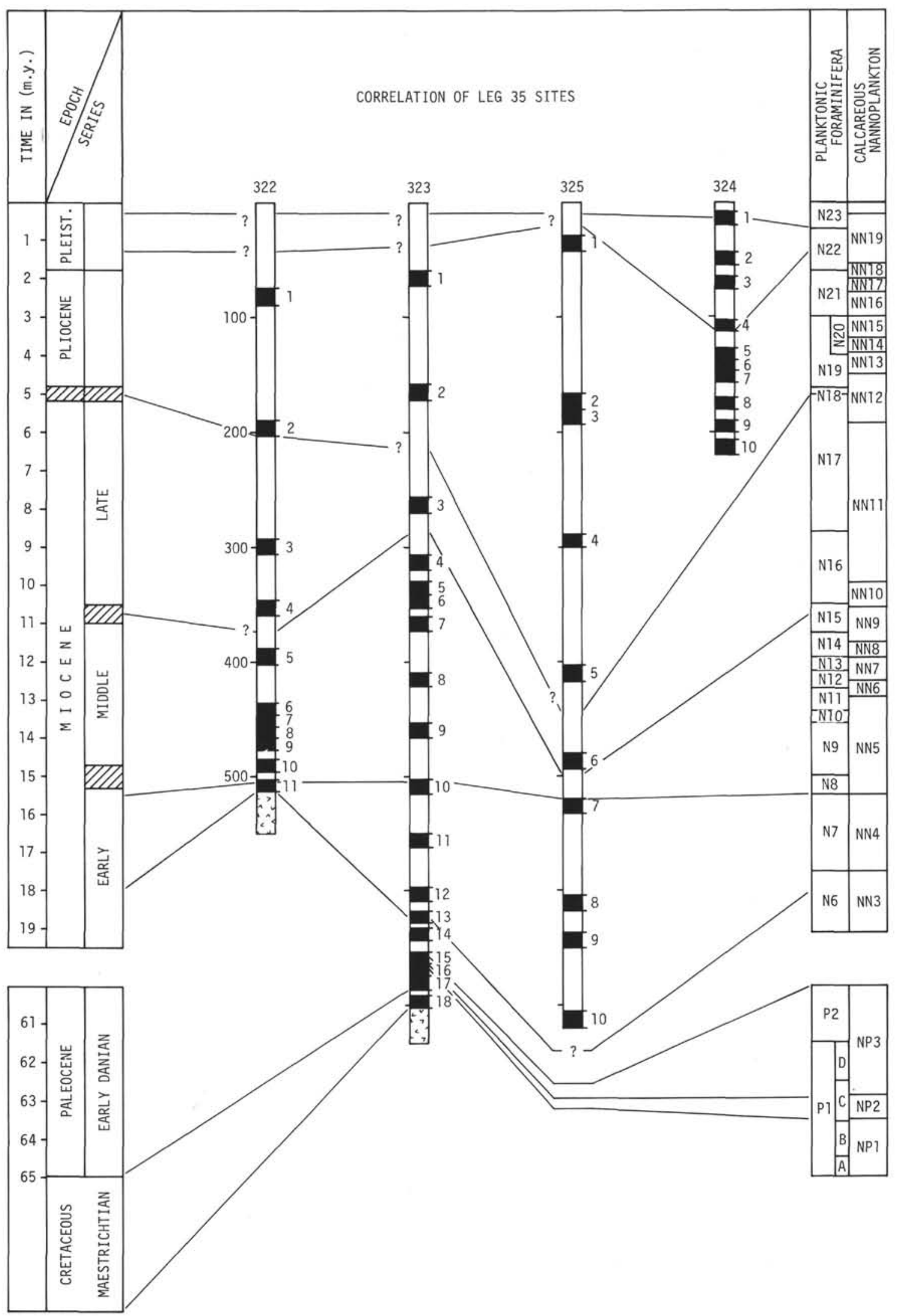

Figure 6. Correlation of Leg 35 drill sites to the absolute time scale (after Berggren, 1973) planktonic foram and calcareous nannoplankton zones are taken from Blow (1969), Martini and Worsley (1970), and Martini (1970). 
Hornibrook, N. de B., 1961. Tertiary foraminifera from Oamaru District (N.Z.). Part 1-Systematics and distribution: Paleont. Bull. New Zealand Geol. Surv., v. 34, p. $1-192$.

Jenkins, D.G., 1973. Should the Altonian of Scott (1972) be rejected or subdivided: New Zealand J. Geol. Geophys., v. 16 , p. $311-318$.

Martini, E., 1970. Standard Paleogene calcareous nannoplankton zonation: Nature, v. 226, 560-561.

Martini, E. and Worsley, T., 1970. Standard Neogene calcareous nannoplankton zonation: Nature, v. 225, p. $289-290$.

McCollum, D.W., 1975. Diatom Stratigraphy of the Southern Ocean In Frakes, L.A., Hayes, D., et al., Initial Reports of the Deep Sea Drilling Project, Volume 28: Washington (U.S. Government Printing Office), p. 515-571.

Schrader, H.-J., 1973. Cenozoic diatoms from the Northeast Pacific, Leg 18. In Kulm, L. D., von Huene, R., et al., Initial Reports of the Deep Sea Drilling Project, Volume 18: Washington (U.S. Government Printing Office), p. 673797.

Walters, R., 1965. The Globoratalia zealandica and G. miozea lineages: New Zealand Geol. Geophys., v. 8, p. 109-127.

Worsley, T., 1974. The Cretaceous-Tertiary boundary event in the ocean. In Studies in paleooceanography: Hay, W.W. (Ed.), S.E.P.M. Spec. Publ. 20, p. 94-125. 